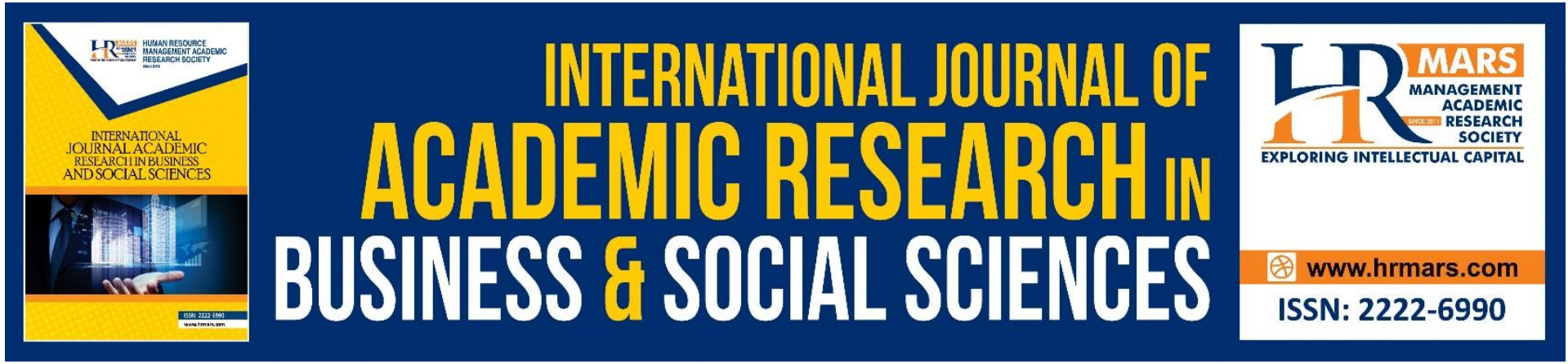

\title{
Relationship between of Behavioral Factors and Fish Detector Technology Usage Among Coastal Fishermen
}

Raidah Mazuki, Asnarulkhadi Abu Samah, Jusang Bolong, and Khairuddin Idris

To Link this Article: http://dx.doi.org/10.6007/IJARBSS/v11-i8/10787 DOI:10.6007/IJARBSS/v11-i8/10787

Received: 07 June 2021, Revised: 11 July 2021, Accepted: 29 July 2021

Published Online: 16 August 2021

In-Text Citation: (Mazuki et al., 2021)

To Cite this Article: Mazuki, R., Samah, A. A., Bolong, J., \& Idris, K. (2021). Relationship between of Behavioral Factors and Fish Detector Technology Usage Among Coastal Fishermen. International Journal of Academic Research in Business and Social Sciences, 11(8), 922-929.

Copyright: (c) 2021 The Author(s)

Published by Human Resource Management Academic Research Society (www.hrmars.com)

This article is published under the Creative Commons Attribution (CC BY 4.0) license. Anyone may reproduce, distribute, translate and create derivative works of this article (for both commercial and non-commercial purposes), subject to full attribution to the original publication and authors. The full terms of this license may be seen at: http://creativecommons.org/licences/by/4.0/legalcode

Vol. 11, No. 8, 2021, Pg. 922 - 929

http://hrmars.com/index.php/pages/detail/IJARBSS

JOURNAL HOMEPAGE

Full Terms \& Conditions of access and use can be found at http://hrmars.com/index.php/pages/detail/publication-ethics 


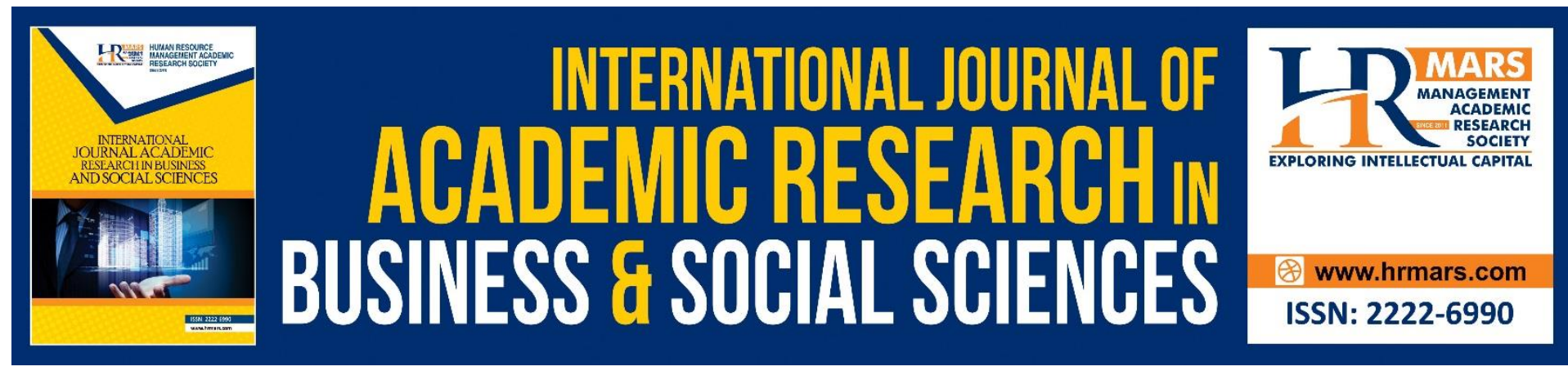

\title{
Relationship between of Behavioral Factors and Fish Detector Technology Usage Among Coastal Fishermen
}

\author{
Raidah Mazuki ${ }^{1}$, Asnarulkhadi Abu Samah',2, Jusang Bolong ${ }^{1,3}$, \\ and Khairuddin Idris ${ }^{1,4}$ \\ ${ }^{1}$ Institute for Social Science Studies, Universiti Putra Malaysia, 43400 Serdang, Selangor, \\ Malaysia, ${ }^{2}$ Faculty of Human Ecology, Universiti Putra Malaysia, 43400 Serdang, Selangor, \\ Malaysia, ${ }^{3}$ Faculty of Modern Language and Communication, Universiti Putra Malaysia, \\ 43400 Serdang, Selangor, Malaysia, ${ }^{4}$ Faculty of Educational Studies, Universiti Putra \\ Malaysia, 43400 Serdang, Selangor, Malaysia \\ Email: raidah0702@gmail.com, asnarulhadi@gmail.com
}

\begin{abstract}
Fish detector technology widely used by commercial fishermen in Malaysia since 1963 . This technology helped in increased efficiency, productivity and eased the work of fishermen. Despite the explosion of fishery knowledge and technology changes, Malaysia's coastal fishermen community appear to lack using the appropriate fish detector technology. There are several factors that probably explain coastal fishermen doubtful to use fish detector technology. One of the prominent factors was behavior factors. Thus, this paper delved the relationship of behavioral factors towards the fish detector technology usage among coastal fishermen by using UTAUT as a main framework. Further, the study was quantitative in nature, and via a multi-stage cluster sampling, a total of 400 coastal fishermen from four selected districts had been selected as the respondents. The SPSS software was used to run an analysis. The results showed that the all four of the behavior factors (Performance expectancy, effort expectancy, social influence and status/personal image) have a positive significant relationship in fish detector technology usage.
\end{abstract}

Keyword: Fish Detector Technology, Technology Usage, Behavior Factor, Coastal Fishermen

Introduction

Fisheries industry help in the growing of food production sub-sector in many countries. Global fish production is estimated to have reached about 179 million tonnes in 2018 with a total first sale value estimated at USD 401 billion, of which 82 million tonnes, valued at USD 250 billion, came from aquaculture production. It is expected that this trend will continue despite several limitations, which may become more challenging in the future (FAO, 2020). Food security, rural development, and poverty alleviation are closely linked. 
Rural development, the process of sustained growth of the rural economy and improvement of well-being of rural community, has various scopes, but it is particularly the development of the agricultural sector, which is widely believed to provide the main impetus not only for reducing poverty and hunger but also for ensuring food security for all. Numerous types of agricultural sector form a vital factor within fisheries development. These can contribute to the improvement of food insecurity, malnutrition and poverty through the provision of food of high nutritional value, income and employment generation, decreased risk of monoculture production failure, improved access to water, enhanced aquatic resource management and increased farm sustainability. Fish and fisheries products are actually recognized not only as some of the healthiest foods on the planet, but also as some of the less impactful on the natural environment. For these reasons, they must be better considered in national, regional and global food security and nutrition strategies, and contribute to the ongoing transformation of food systems to ensure in elimination hunger and malnutrition. (e.g. FAO, 2000a, Prein and Ahmed, 2000, FAO, 2020).

In order to alleviate the rural sector, the fisheries community that still in the mood of the conventional wisdom need to shift into a technology. Since it will provide more efficient in work and increase the production. Furthermore, the production-oriented and capital intensive technologies employed by international assistance programmes and equally shared by national policy makers primarily in their desire to increase export earnings often generate negative impact on employment, nutrition, changing values, ethics, resource use rights and policy implications in many of the third world countries. In the context of fisheries, an open access resource and competition among sectors resembles a "zero-sum game" where technological advantage favours the minority and limits the ability of the majority to earn adequate income, employment and food.

Modern fishing technology plays an important role in the development of fishermen. Fishing technology has increased efficiency and eased the work of fishermen. The ability of fish detector technology to find the school of fish and or advance vessel can be expected to increase the fishermen' income. Hence, fishermen have to prepare themselves with a good skills and enough knowledge. Yet, the dissemination of the knowledge is still lacking for this particular group with some reasons. The usage of fishing technology was still at the low level among the coastal fishermen in Malaysia (Omar et al., 2012; Mazuki, 2014).

There are several factors that probably explain coastal fishermen doubtful to use fish detector technology. This is because human behavior is guided by behavior factors. Abundance of study tried the best to explain the behavior factors that influence the technology usage among community. Therefore, UTAUT is important model to understand usage of technology among the community. Behavioral factors create a favorable or unfavorable attitude toward technology usage by the social influence (family, friends and agency) from the community (Schmitz \& Fulk,1991; Venkatesh and Morris, 2000; Fulk \& Yuan, 2017). In order to use the technology, the community should have effort expectancy. Effort expectancy reflects the constraints of technology usage such as small screens and inconvenient input have made it relatively problematic for users to search for information. Thus, effort expectancy will affect user satisfaction. Furthermore, performance expectancy has an impact the perceived utility associated with technology usage among community. A frequent technology usage was proved improving users' living, working performance and efficiency (Bhattacherjee, 2001). 
Personal image or status is critical for many people in a community. When usage of fish detector technology is not extensive, users may regard these devices as symbolic of fashion and wealth, and adopt these devices to enhance their sense of self-importance. Thus, this study will lead to a deep understanding of potential behaviour factors to impinge fish detector usage among coastal fishermen.

\section{Methodology}

Generally, fishermen in Malaysia can be divided into two main groups, coastal fishermen (Zone A and Zone B) and deep-sea / commercial fishermen (Zone CO and Zone C2). This study required coastal fishermen among peninsular Malaysia. The characteristics of small scale fishermen / coastal fishermen fishing operation are smaller boat or boat fibers, lower engine power, short duration of fishing operations, small catching capacity, still using traditional methods with basic communication tools (mobile phones).

This study used a multi stage cluster sampling because of the unavailability of complete list of all members of the population. At the first stage, all of the states were grouped according to their zone (Southern, Northern, Central and East Coast). Next, a state was randomly select to represent their respective zone. In the second stage, all the fisheries districts of the selected states were listed and then, a fisheries district will be randomly selected to represent their respective state. In the third stage, a total of 100 registered coastal fishermen were selected as the respondents and representing their respective fisheries district. Thus, a total of 400 coastal fishermen data were collected from four zones (Southern, Northern, Central and East Coast).

This study used a set of questionnaire for data collection. The questionnaire was designed based on the theory and existing literature on the unified theory of acceptance and use of technology (UTAUT) that was formulated by Venkatesh and others. While on the field, the younger respondents were answered the questionnaire by themselves (self-administered). Further, a face-to-face interviewed were conducted for the older generation, illiterate and those who have a bad eyes vision. The interviewer read all the questions and the respondents will answer immediately based on their perception on the fish detector technology usage. The whole process of data collection was monitored by the researcher and experienced enumerator. This study used descriptive to portray the frequency and percentage of the selected demographic profile. Inferential analysis were employed in order to describe the behavioral factors relationship towards the fish detector technology usage.

\section{Results and Discussion}

Table 1 represents the distribution of frequencies and percentages of the demographic profile of the respondents. The results were focusing on ethnicity, age, level of education level, average monthly income, years in fishing and average days going to sea in a month. Table 1 indicates that majority of the coastal fishermen were Malays (96.3\%) with the age between 21 to 40 years old (50.5\%). Moreover, 181 of respondents possessed upper secondary school education. The average coastal fishermen monthly income was between RM961 to RM1500 (45.5\%). Most of the respondents (41.3\%) have experience in fishing between 1 to 10 years with the average days 16 to 20 days in a month. 
Table 1: The Demographic Profile of Respondents $(n=400)$

\begin{tabular}{|c|c|c|}
\hline Variable & Frequency & Percentage (\%) \\
\hline \multicolumn{3}{|l|}{ Ethnicity } \\
\hline Malay & 385 & 96.3 \\
\hline Chinese & 15 & 3.8 \\
\hline \multicolumn{3}{|l|}{ Age (years) } \\
\hline$\leq 20$ & 12 & 3.0 \\
\hline $21-40$ & 202 & 50.5 \\
\hline $41-60$ & 150 & 37.5 \\
\hline $61-80$ & 36 & 9.0 \\
\hline \multicolumn{3}{|l|}{ Level of Education } \\
\hline Not going to school & 10 & 2.5 \\
\hline Primary School (Standard 1-6) & 92 & 23.0 \\
\hline Lower Secondary School (Form 1-3) & 105 & 26.3 \\
\hline Upper Secondary School (Form 4-5) & 181 & 45.3 \\
\hline Tertiary Education (Form 6 -PhD) & 12 & 3.0 \\
\hline \multicolumn{3}{|l|}{ Average Monthly Income } \\
\hline$\leq \mathrm{RM} 960$ & 53 & 13.3 \\
\hline RM 961-1500 & 182 & 45.5 \\
\hline RM 1501-2500 & 107 & 26.8 \\
\hline$\geq \mathrm{RM} 2501$ & 58 & 14.5 \\
\hline \multicolumn{3}{|l|}{ Years in fishing } \\
\hline $1-10$ & 165 & 41.3 \\
\hline $11-20$ & 113 & 28.2 \\
\hline $21-30$ & 56 & 14.0 \\
\hline More than 31 & 66 & 16.5 \\
\hline \multicolumn{3}{|l|}{ Average days going to sea in a month } \\
\hline$\leq 15$ & 59 & 14.8 \\
\hline $16-20$ & 228 & 57.0 \\
\hline $21-25$ & 105 & 26.3 \\
\hline$\geq 26$ & 8 & 2.0 \\
\hline
\end{tabular}

Table 2 presented results for the relationship between four factors studied towards the fish detector technology usage among the respondents studied. Inferential analysis using Pearson product-moment correlation was used to discover any relationship that may exist between the four factors with fish detector technology usage. Results showed that all the five constructs have positive significant relationship with the fish detector technology usage.

Performance expectancy found to has a high correlation ( $r=0.565)$ towards fishing detector technology usage among coastal fishermen in Malaysia. In parallel to past studies, this factor revealed to have a relationship with the technology usage in many studies (Sang, et. al, 2010; Kim \& Park, 2012; Voutinioti, 2013; Venkatesh, et. al, 2016; Shin, et. al., 2017). It is a relevant 
factor since it resulted in enhancing the performance of fishing operation when using the fish finder technology among the coastal fishermen. Nowadays, there was a rapid change of the technology innovation. The respondents of the study keen to use the fish detector technology because of the effectiveness in changing their pattern of fishing. The fishing operation would become faster and shortening the time. On top of that, their level of confidence was increased when they used it. This is because they already know where the school of fish would be gathered. The fish detector also be able to detect coral reef or sinking boat. It helped in reducing the damage of the net and the boat.

Furthermore, the result also indicates that effort expectancy have high correlation towards fish detector technology usage. An easy and friendly user of fishing technology will initiate the behavior of coastal fishermen to use the technology. As Venkatesh et al (2003), explained that the effort expectancy as the expected complexity of the technology and the level of energy needed to use it. The easiness to understand the function and language provided were important to the coastal fishermen since there is a ICT gap between rural and urban. A straightforward instructions provided will help the coastal fishermen to operate the fishing technology easily.

Personal image/status found to have moderate relationship ( $r=.326)$ towards fish detector technology usage among coastal fishermen. Competition for status is an important in one community. The values of belonging, social recognition, conformity, and preserving public image are particularly strong in collectivistic societies (Triandis et. al, 1990). Higher production in fishing operation is representative of the wealth, independence and sustainability of rural livelihoods. Specifically, coastal fishermen in higher socioeconomic status are more likely to have numerous advance and modern fishing technology than the lower income coastal fishermen. Higher status people generally have a wider range of activity, larger number of reference groups, and interpersonal contacts in which always discussed any new topics with others.

On the other hand, there was a low relationship ( $r=.268$ ) of social influence towards fish detector technology usage among coastal fishermen. Majority of the respondents were only possessed upper secondary school education. This may lead to the ignorance of using the technology (Morris and Venkatesh, 2000). Furthermore, the locality of the study effects the intention to use the fish detector technology. People who lived in the rural area were less attracted and sometimes have limited access to learn the innovation of the new technology (Hindman, 2000). Social influence among coastal fishermen will validate the actions of fishing technology usage via a positive word-of-mouth and recommendations (Casaló et al., 2008, Hallowell, 1996). Their opinions will affect coastal fishermen decision on fishing technology usage (Hong et. al., 2008).

Table 2: The Behavioral Factors Relationship towards the fish detector technology Usage

\begin{tabular}{lll}
\hline Behavioural Factor & $\mathbf{r}$ & $\mathbf{p}$ \\
\hline Performance Expectancy & .565 & .000 \\
Effort Expectancy & .482 & .000 \\
Social Influence & .268 & .000 \\
Personal Image/Status & .326 & .000 \\
\hline
\end{tabular}




\section{Conclusion and Recommendation}

In a nutshell, it is essential for fishermen communities to transform their traditional fishing technology to the modern and advanced fishing technology. It would make enormous advantages and have big opportunities to be accessible for improvement since the fisheries sector is a main source for foreign exchange and essentially as a source of aquatic protein.

Fishermen community has always the main focus of rural development program because the rural areas always linked to inadequate information. The availability of PNK for ensuring that fishermen community to receive the information about the fish detector. Thus, it can reduce the digital divide between urban and rural community. Last but not least, modern fishing technology adoption is needed for developing both; the fishermen community and the rural areas. To certify this, policy makers and related parties need to check the availability of basic infrastructure such as fish landing jetty or fish market that accessible for community. The existing of extensive diversity of modern fishing technologies will support the traditional method, and it is important to think about it.

\section{References}

Bhattacherjee, A., \& Premkumar, G. (2004). Understanding Changes in Belief and Attitude toward Information Technology Usage: A Theoretical Model and Longitudinal Test. MIS Quarterly, 28(2), 229-254. doi:10.2307/25148634

Casaló, L. V., Flavián, C., \& Guinalíu, M. (2008). The role of satisfaction and website usability in developing customer loyalty and positive word-of-mouth in the e-banking services. International Journal of Bank Marketing, 26(6), 399-417.

Hallowell, R. (1996). The relationships of customer satisfaction, customer loyalty, and profitability: an empirical study. International Journal of Service Industry Management, 7(4), 27-42.

Hamzah, A., Krauss, S. E., Shaffril, H. A., Suandi, T., Ismail, I. A., \& Abu Samah, B. (2014). Toward understanding Malaysian fishermen's decision making on the use of fishing technology: A mental model approach. International Journal of Psychology, 49(5), 397403.

Hindman, D. B. (2000). The rural-urban digital divide. Journalism \& Mass Communication Quarterly, 77(3), 549-560.

Hong, S. J., Thong, J. Y., Moon, J. Y., \& Tam, K. Y. (2008). Understanding the behavior of mobile data services consumers. Information Systems Frontiers, 10(4), 431.

Morris, M. G., and Venkatesh, V. (2000). Age differences in technology adoption decisions: implications for a changing work force. Personnel Psychology, 53(2), 375403. https://doi.org/10.1111/j.1744-6570.2000.tb00206.x

Mazuki, R., \& Man, N. (2014). Acceptance of technology among Malaysian fishermen. Asian Social Science, 10(16), 1. DOI:10.5539/ass.v10n16p1

Omar, S. Z., Shaffril, H. A. M., Bolong, J., D’Silva, J. L., \& Abu Hassan, M. (2012). Usage of offshore ICT among fishermen in Malaysia.Journal of Food, Agriculture and Environment, 10(3\&4), 1315-1319.

Prein, M., \& Ahmed, M. (2000). Integration of aquaculture into smallholder farming systems for improved food security and household nutrition. Food and nutrition bulletin, 21(4), 466-471.

Sang, G., Valcke, M., Van Braak, J., \& Tondeur, J. (2010). Student teachers' thinking processes and ICT integration: Predictors of prospective teaching behaviors with educational 
technology. Computers \& Education, 54(1), 103-112.

Schmitz, J., \& Fulk, J. (1991). Organizational colleagues, media richness, and electronic mail: A test of the social influence model of technology use. Communication research, 18(4), 487-523.

Shin,Y. M., Lee, S. C., Shin, B., and Lee, H. G. (2010) Examining influencing factors of postadoption usage of mobile Internet: Focus on the user perception of supplier-side attributes. Information Systems Frontier, 12(5), 595-606.

Triandis, H. C. (1979). Values, attitudes, and interpersonal behavior. In Nebraska symposium on motivation. University of Nebraska Press.

Venkatesh, V., \& Morris, M. G. (2000). Why don't men ever stop to ask for directions? Gender, social influence, and their role in technology acceptance and usage behavior. MIS quarterly, 115-139.

Venkatesh, V., Morris, M. G., Davis, G. B., \& Davis, F. D. (2003). User acceptance of information technology: Toward a unified view. MIS quarterly, 425-478.

Venkatesh, V., Thong, J. Y. L., Statistics, B., Xu, X., \& Acceptance, T. (2016). Unified Theory of Acceptance and Use of Technology: A Synthesis and the Road Ahead. Jais, 17(5), 328376. Retrieved from

http://www.vvenkatesh.com/wpcontent/uploads/dlm_uploads/2016/01/2016_JAIS_Venkat esh-et-al.-UTAUT.pdf

Voutinioti, A. (2013). Determinants of user adoption of e-Government Services in Greece and the role of citizen service Centres. Procedia Technology, 8, 238-244. 